\title{
RANCANG BANGUN APLIKASI KAMUS TUMBUHAN BERSPORA BERBASIS ANDROID DARI HASIL STUDI TUMBUHAN BERSPORA DI TAMAN WISATA ALAM PANTAI PANJANG
}

\author{
Amira Tuzzahra $^{1 *}$ Kasrina $^{1}$, Irwandi Ansori ${ }^{1}$ \\ ${ }^{1}$ Program Studi Pendidikan Biologi Fakultas Keguruan dan Ilmu Pendidikan, Universitas Bengkulu \\ Email*: amirah.hawking58@yahoo.com
}

\begin{abstract}
Abstrak
Penelitian ini bertujuan untuk mengetahui kelayakan Aplikasi Kamus Tumbuhan Berspora Berbasis Android yang dirancang dari hasil studi tumbuhan berspora di Taman Wisata Alam (TWA) Pantai Panjang Kota Bengkulu. Subjek dari penelitian ini adalah mahasiswa Pendidikan Biologi angkatan 2016 Universitas Bengkulu. Teknik pengumpulan data pada penelitian ini berupa angket. Instrumen yang digunakan berupa lembar angket validasi untuk dua orang dosen ahli (ahli materi dan ahli media) dan lembar uji respon untuk mahasiswa. Berdasarkan hasil studi ditemukan 39 spesies tumbuhan berspora yang kemudian dibuat menjadi data dari aplikasi kamus tumbuhan berspora yang kemudian divalidasi oleh dua validator, aplikasi yang dirancang memperoleh predikat sangat layak dengan rata-rata persentase sebesar $93,5 \%$. Sementara dari hasil uji respon mahasiswa diperoleh predikat sangat baik dengan rata-rata persentase sebesar $92,81 \%$. Berdasarkan hasil uji validitas dan uji respon tersebut, Aplikasi Kamus Tumbuhan Berspora berbasis lingkungan yang dirancang layak untuk digunakan sebagai media pendukung perkuliahan Taksonomi Tumbuhan I pada materi tumbuhan berspora.
\end{abstract}

Kata Kunci: Android, Bengkulu, Kamus, Spora, TWA.

\begin{abstract}
This study aimed to determine the feasibility of an Android-based spore-producing plants dictionary application designed from the results of a study of spore-producing plants in the Nature Tourism Park (NTP) of Pantai Panjang, Bengkulu City. The subjects of this study were students of 2016 biology education at the University of Bengkulu. The data collection technique in this study were questionnaires. The instruments used were validation questionnaires for two expert lecturers (content expert lecturer and media expert lecturer) and response test sheets for students. Based on the results of the study, there were found 39 species spore-producing plants that processing into the data of spore-producing plants dictionary application that validated by two validators, the application designed to obtain a very decent predicate with an average percentage of $93.5 \%$. While the results of the students response tests obtained a very good predicate with an average percentage of $92.81 \%$. Based on the results of the validity tests and response tests, the designed spore-producing plants dictionary application based on local environment is feasible to be used as a supporting media for lecturing on the Plant Taxonomy I on spore-producing plants topics.
\end{abstract}

Keywords: Android, Bengkulu, Dictionary, Spores, NTP.

\section{PENDAHULUAN}

Taksonomi merupakan ilmu pengetahuan yang mencakup identifikasi, tatanama, dan klasifikasi objek yang biasanya terbatas pada objek biologi (Lawrence, 1951). Taksonomi tumbuhan menjadi mata kuliah yang dipelajari di program studi Pendidikan Biologi Universitas Bengkulu, yang terbagi menjadi 2 mata kuliah, yaitu Taksonomi Tumbuhan I (TT I) yang mempelajari tumbuhan rendah (yang belum berpembuluh) dan tumbuhan peralihan, dan Taksonomi Tumbuhan II (TT II) yang mempelajari tumbuhan tinggi (yang sudah berpembuluh).

Sesuai dengan namanya, mata kuliah TT I merupakan mata kuliah dasar dalam mempelajari taksonomi tumbuhan, termasuk tumbuhan berspora. Tumbuhan berspora adalah tumbuhan yang memiliki spora dan memakai spora sebagai alat 
perkembangbiakannya.

Tumbuhan berspora terdiri atas tumbuhan lumut (Bryophyta) dan tumbuhan paku (Pteridophyta) yang memiliki banyak spesies. Tumbuhan berspora dapat hidup hampir disemua tempat, termasuk di TWA Pantai Panjang Kota Bengkulu yang sering dijadikan lokasi praktikum lapangan oleh mahasiswa pendidikan biologi UNIB.

Ada banyak istilah, nama latin, dan bagian dari tumbuhan dalam mempelajari taksonomi tumbuhan termasuk pada materi tumbuhan berspora yang belum diketahui oleh mahasiswa (Tijtrosoepomo, 1991).

Padatnya materi dalam mata kuliah TT I diikuti oleh kebutuhan akan media pembelajaran yang efektif dan efisien. Dalam era digital ini tentunya media pembelajaran berbasis perangkat mobile seperti android akan sangat berguna bagi mahasiswa. Namun, lama dan kurangnya pengetahuan membuat dosen belum bisa membuat media pembelajaran berbasis android. Sedangkan materi TT I seiring waktu juga terdapat perbaharuan sehingga dibutuhkan media pembelajaran yang dapat dengan mudah memperbaharui dan menyebarkan pembaharuan tersebut kepada mahasiswa.

Ada cara yang lebih efektif untuk membantu mahasiswa dan dosen dalam hal ini, yaitu dengan cara membuat media pembelajaran yang dapat terhubung langsung dengan mereka dan mudah diakses, salah satunya adalah kamus berbasis android.

Menurut Kamus Besar Bahasa Indonesia (2018), pengertian kamus adalah buku acuan yang memuat kata dan ungkapan yang biasanya disusun menurut abjad berikut keterangan maknanya, pemakaiannya dan terjemahannya serta digunakan sebagai rujukan yang menerangkan makna kata - kata yang berfungsi untuk membantu seseorang mengenal perkataan baru. Pada era modern ini, ada yang dinamakan Kamusta. Kamusta merupakan sebuah aplikasi kamus yang dirancang dengan mode offline dan online yang dapat menerjemahkan dari bahasa Indonesia ke bahasa lain dan sebaliknya (Budiman dkk, 2015).

Kamusta atau aplikasi kamus tersebut bisa diakses melalui android. Android merupakan salah satu platform dari perangkat smartphone. Salah satu keutamaan dari android yaitu lisensinya bersifat terbuka (open source) dan gratis (free) sehingga bebas untuk dikembangkan karena tidak ada biaya royalti maupun didistribusikan dalam bentuk apapun. Hal ini memudahkan para programmer untuk membuat aplikasi baru di dalamnya, termasuk aplikasi kamus seperti Kamusta (Lengkong dkk, 2015).

Berdasarkan latar belakang tersebut, maka peneliti merasa perlu untuk melakukan penelitian berjudul "Rancang Bangun Kamus Tumbuhan Berspora Berbasis Android dari Hasil Studi di Taman Wisata Alam Kota Bengkulu"

(Bryophyta) dan tumbuhan paku (Pteridophyta) yang memiliki banyak spesies. Tumbuhan berspora dapat hidup hampir disemua tempat, termasuk di TWA Pantai Panjang Kota Bengkulu yang sering dijadikan lokasi praktikum lapangan oleh mahasiswa pendidikan biologi UNIB.

Ada banyak istilah, nama latin, dan bagian dari tumbuhan dalam mempelajari taksonomi tumbuhan termasuk pada materi tumbuhan berspora yang belum diketahui oleh mahasiswa (Tijtrosoepomo, 1991). 
Padatnya materi dalam mata kuliah TT I diikuti oleh kebutuhan akan media pembelajaran yang efektif dan efisien. Dalam era digital ini tentunya media pembelajaran berbasis perangkat mobile seperti android akan sangat berguna bagi mahasiswa. Namun, lama dan kurangnya pengetahuan membuat dosen belum bisa membuat media pembelajaran berbasis android. Sedangkan materi TT I seiring waktu juga terdapat perbaharuan sehingga dibutuhkan media pembelajaran yang dapat dengan mudah memperbaharui dan menyebarkan pembaharuan tersebut kepada mahasiswa.

Ada cara yang lebih efektif untuk membantu mahasiswa dan dosen dalam hal ini, yaitu dengan cara membuat media pembelajaran yang dapat terhubung langsung dengan mereka dan mudah diakses, salah satunya adalah kamus berbasis android.

\section{METODE}

Penelitian ini merupakan penelitian berjenis $\mathrm{R}$ \& $\mathrm{D}$ (Research and Development) yang dikembangkan oleh Sugiyono (2008) yang disesuaikan dengan kebutuhan peneliti. Penelitian ini telah dilaksanakan pada bulan Mei 2019 di Program Studi Pendidikan Biologi UNIB. Subjek dari penelitian ini adalah dua orang dosen Pendidikan Biologi UNIB dan mahasiswa Pendidikan Biologi UNIB angkatan 2016. Teknik pengumpulan data dalam penelitian ini menggunakan lembar angket yang terdiri atas angket uji validasi (untuk dosen ahli materi dan media) dan angket uji respon (untuk mahasiswa). Data uji validasi yang terkumpul dianalisis secara deskriptif kuantitatif. Angka yang diperoleh dari uji validasi diubah dalam persentase kelayakan dengan rumus:

$$
=\frac{\text { Jumlah skor lembar validasi }}{\text { Skor maksimal }} \times 100 \%
$$

Hasil perhitungan persentase kelayakan aplikasi kemudian diinterpretasikan ke dalam kategori-kategori tertentu yang bersifat kualitatif menurut Riduwan (2013) yang dapat dilihat pada Tabel 1.

Tabel 1. Interpretasi Skor Uji Validasi

\begin{tabular}{ll}
\hline Presentase & Kriteria \\
\hline $0 \%-20 \%$ & Sangat Tidak Layak \\
$21 \%-40 \%$ & Tidak Layak \\
$41 \%-60 \%$ & Cukup Layak \\
$61 \%-80 \%$ & Layak \\
$81 \%-100 \%$ & Sangat Layak
\end{tabular}

Sementara untuk hasil uji respon mahasiswa digunakan rumus:

$$
\mathrm{X}=\frac{\sum X}{n} \mathrm{x} 100 \%
$$

Dengan keterangan:

$\mathrm{X}=$ Skor rata-rata

$\Sigma \mathrm{X}=$ Jumlah skor

$\mathrm{n} \quad=$ Jumlah penilai (Widoyoko, 2016).

Kemudian skor diinterpretasikan dengan rentang yang telah ditentukan pada Tabel 2.

Tabel 2. Interpretasi Skor Uji Respon

\begin{tabular}{llll}
\hline No & $\begin{array}{l}\text { Rentang } \\
\text { kuantitatif }\end{array}$ & skor & $\begin{array}{l}\text { Kategori } \\
\text { Kualitatif }\end{array}$ \\
\hline 1 & $X>85 \%$ & Sangat Baik \\
2 & $70 \%<X \leq 85 \%$ & Baik \\
3 & $55 \%<X \leq 70 \%$ & Cukup Baik \\
4 & $40 \%<X \leq 55 \%$ & Kurang Baik \\
\hline & & (Widoyoko, 2016).
\end{tabular}




\section{HASIL DAN PEMBAHASAN}

Berdasarkan hasil studi yang telah dilakukan terlebih dahulu di TWA Pantai Panjang Kota Bengkulu, ditemukan 39 spesies tumbuhan berspora yang kemudian dari data tersebut dibuat aplikasi kamus tumbuhan berspora yang divalidasi oleh dua orang dosen Biologi sebagai validator dengan hasil validasi yang tertera pada Tabel 3.

Tabel. 3 Hasil Validasi Aplikasi Kamus Tumbuhan Berspora oleh Dosen Ahli

\begin{tabular}{llll}
\hline Validator & Aspek & Presentase & Kriteria \\
\hline Validator 1 & Kelayakan Materi & $97 \%$ & Sangat Layak \\
(Ahli Materi) & Penyajian Materi & & \\
Validator 2 & Kegrafisan & $90 \%$ & Sangat Layak \\
(Ahli Media) & Kebahasaan & & \\
\hline \multicolumn{2}{l}{ Rata-rata persentase } & $\mathbf{9 3 , 5 \%}$ & Sangat Layak
\end{tabular}

Dari hasil validasi oleh dua orang dosen

1. Penambahan menu Kunci ahli (dosen ahli materi dan dosen ahli media) dapat dilihat bahwa Aplikasi Kamus Determinasi pada aplikasi kamus tumbuhan berspora.

Tumbuhan Berspora yang dirancang berada dalam kriteria sangat layak dan

2. Pemberian sekat pada tiap kelompok kata.

boleh diujikan kepada mahasiswa, namun tetap ada beberapa poin dari validator untuk dilakukannya perbaikan terhadap aplikasi, yaitu:

3. Penambahan submenu cara penggunaan, biografi peneliti, dan tinjauan pustaka.

Perbaikan-perbaikan ini dapat dilihat pada Gambar 1, Gambar 2, dan Gambar 3.

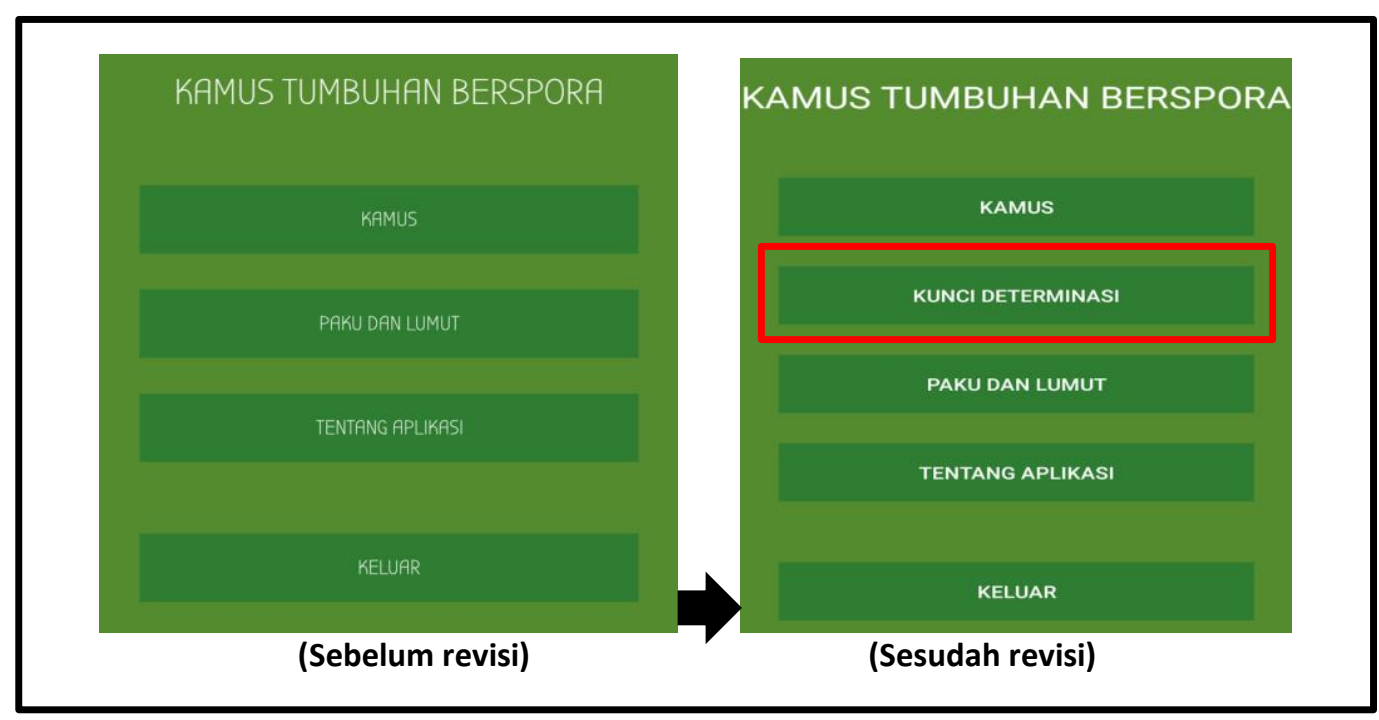

Gambar 1. Penambahan menu kunci determinasi 


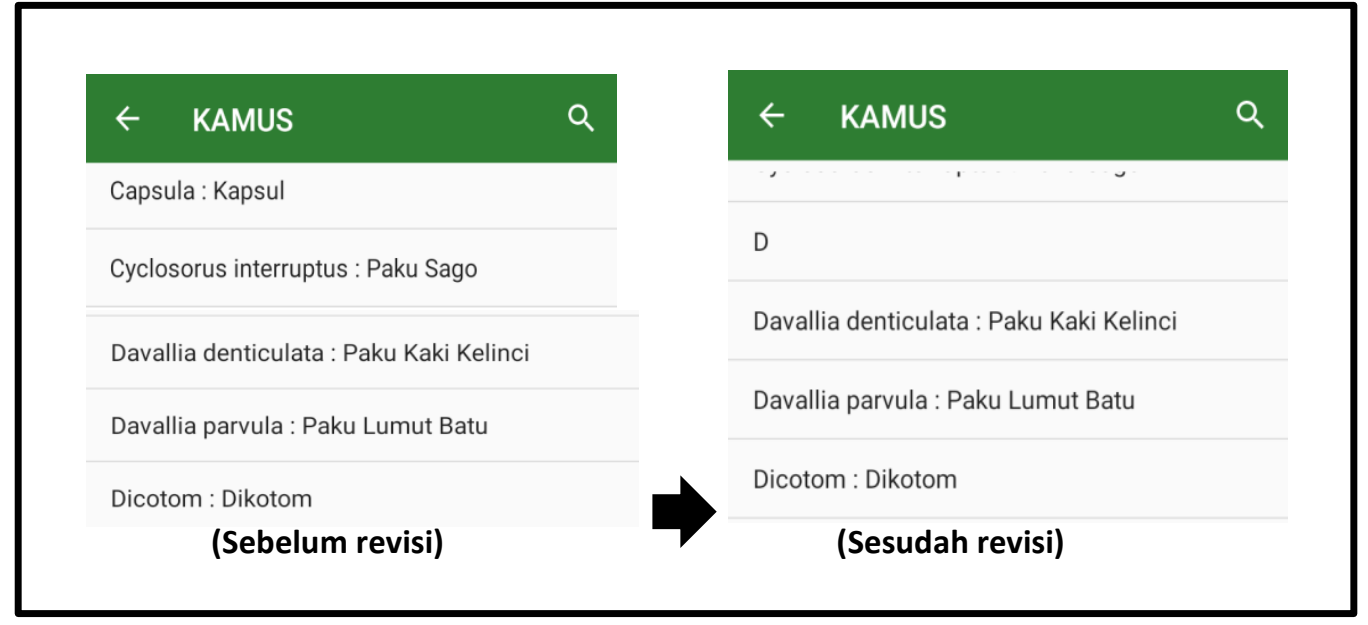

Gambar 2. Pemberian sekat pada tiap kelompok kata

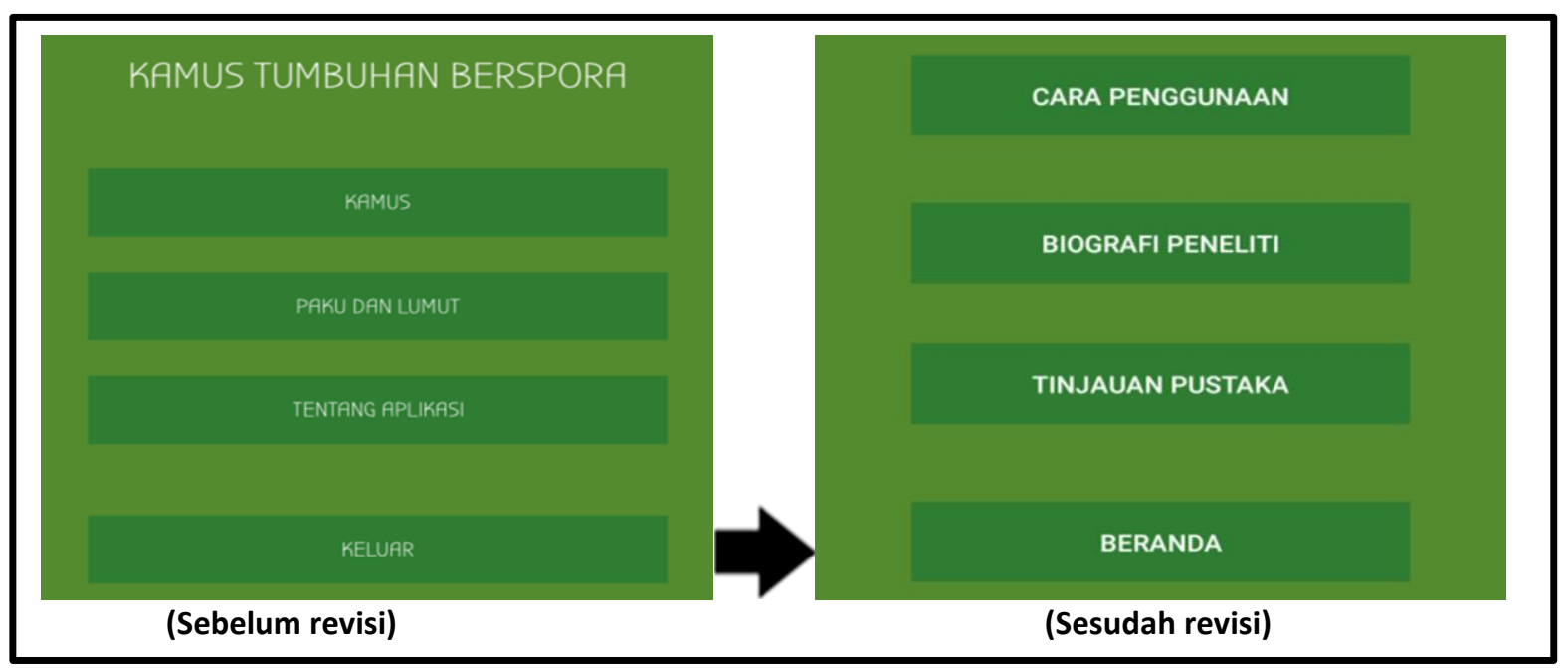

Gambar 3. Penambahan submenu cara penggunaan, biografi peneliti, dan tinjauan pustaka

Revisi desain pada aplikasi bertujuan untuk memperbaiki kekurangan yang ada pada format awal aplikasi sehingga aplikasi menjadi layak untuk diujikan kepada mahasiswa. Seperti yang terlihat pada Gambar 1, sebelum direvisi, hanya ada 4 menu utama, yaitu menu kamus, paku dan lumut, tentang aplikasi, dan keluar. Namun setelah direvisi ditambahkan menu kunci determinasi yang akan sangat berguna untuk kegiatan perkuliahan terutama yang dilakukan di luar ruangan (outdoor). Sementara pada Gambar 2, terlihat sebelumnya tidak ada sekat perkelompok kata (sesuai abjad), sehingga semua kata bercampur, setelah direvisi, setiap kelompok kata sudah ada sekat, sehingga akan lebih memudahkan pengguna dalam mencari dan melihat kata yang diinginkan. Kemudian pada Gambar 3 , sebelum revisi hanya ada menu tentang aplikasi yang di dalamnya hanya terdapat cara penggunaan dan nama peneliti saja. Namun, setelah direvisi, menu tentang aplikasi dibuat submenu-submenunya berupa submenu cara penggunaan, biografi peneliti, tinjauan pustaka, dan beranda. keempat submenu ini akan 
mempermudah pengguna dalam pustaka apa saja yang dirujuk oleh menggunakan aplikasi serta mencari tahu peneliti.

info mengenai peneliti dan tinjauan

Setelah selesai direvisi, selanjutnya dilakukan uji respon terhadap mahasiswa Pendidikan Biologi UNIB angkatan 2016 dengan hasil uji respon sebagai berikut:

Tabel 4. Hasil Uji Respon oleh Mahasiswa Pendidikan Biologi UNIB Angkatan 2016 Terhadap Aplikasi Kamus Tumbuhan Berspora

\begin{tabular}{ccccc}
\hline No & Komponen yang divalidasi & Rerata & Persentase & Kategori \\
\hline 1. & Aspek Grafika & 7,5 & $93,75 \%$ & Sangat Baik \\
2. & Aspek Bahasa & 7,4 & $92,50 \%$ & Sangat Baik \\
3. & Aspek Penyajian & 7,6 & $95,00 \%$ & Sangat Baik \\
4. & Aspek Materi/Isi & $\mathbf{7 , 2}$ & $90,00 \%$ & Sangat Baik \\
\hline & Total & $\mathbf{2 9 . 7}$ & $\mathbf{9 2 , 8 1 \%}$ & Sangat Baik \\
\hline
\end{tabular}

Hasil uji respon mahasiswa mendapati rerata skor $7,5(93,75 \%)$ untuk aspek grafika, skor 7,4 (92,50\%) untuk aspek bahasa, skor 7,6 (95,00\%) untuk aspek penyajian, dan skor 7,2 (90,00\%) untuk aspek materi, sehingga diperoleh rerata skor 7,43 (92,81\%) dengan kategori sangat baik. Pada aspek grafika, dinilai layout, pemilihan tulisan, gambar, dan tata letaknya. Skor yang didapati dari aspek ini adalah 7.5 dengan kategori sangat baik, dapat dilihat bahwa grafis sangat berpengaruh pada respon dari mahasiswa, karena grafis aplikasi yang bagus dapat meningkatkan minat pemakainya, terutama pada media pembelajaran, haruslah dibuat yang dapat menarik minat mahasiswa.

Hal ini sesuai dengan penelitian Sa'diyati (2011) yang mengatakan tampilan media dan bahan ajar haruslah menarik minat mahasiswa. Hal ini sesuai dengan pendapat Angkowo (2007: 26) bahwa secara khusus media gambar berfungsi untuk menarik perhatian, memperjelas sajian ide, mengilustrasikan atau memberi variasi pada suatu fakta yang kemungkinan akan dilupakan atau diabaikan.

Selanjutnya pada aspek bahasa dengan dua indikator penilaian yakni bahasa sesuai dengan EYD dan bahasa yang digunakan jelas dan mudah dipahami. Pada aspek bahasa dengan rerata skor yang didapatkan 7,4 dengan presentase keidealan 92,50\% dengan kategori baik. Hal ini sejalan dengan penelitian Sa'diyati (2011) bahan dan media ajar harus sesuai dengan perkembangan peserta didik, komunikatif, dialogis dan interaktif, lugas, koherensi keruntutan alur pikir, kesesuaian dengan kaidah bahasa Indonesia yang benar dan penggunaan istilah/simbol sudah baik. Pemilihan bahan ajar dan metode mengajar hendaknya memperhatikan prinsip perkembangan, dan prinsip perbedaan individu. Dalam 
komponen kebahasaan, tidak kalah penting pula poin dialogis dan interaktif, poin ini harus ada dalam bahan ajar karena poin ini mendukung mahasiswa untuk tetap termotivasi untuk membaca dan mempelajari isinya serta membantu mahasiswa lebih mudah memahami karena seolah- olah mahasiswa dapat berinteraksi walau bahan ajar tersebut digunakan tanpa adanya panduan dosen.

Pada aspek penyajian terdapat dua indikator yang dinilai yakni penyajian aplikasi menarik, serta praktis dan mudah digunakan. Berdasarkan grafik 4.1 dapat disimpulkan bahwa respon mahasiswa sangat baik dengan skor 7,6 atau persentase 95,00\%, yang menunjukkan bahwa respon paling tinggi dari mahasiswa ada pada aspek penyajian ini. Hal ini sejalan dengan penelitian Sa'diyati (2011) penyusunan media dan bahan ajar ini selalu mengupayakan untuk bisa menarik perhatian, sehingga mahasiswa tertarik untuk membaca dan mempelajarinya.

Pada aspek materi/isi terdapat 2 indikator yang dinilai yakni 1) Materi dalam aplikasi kamus berhubungan dengan materi perkuliahan sehingga dapat membantu mempermudah proses belajar; 2) Materi yang terdapat dalam aplikasi kamus bagus dan sesuai dengan tema perkuliahan. Berdasarkan grafik 4.2 bahwa respon mahasiswa dalam menilai aplikasi pada aspek materi/isi dengan rerata skor yang didapatkan 7,2 dengan presentase keidealan 90,00 \% dengan kategori sangat baik. Hal ini sejalan dengan penelitian Ulviani (2017) yang mengatakan aspek materi/isi haruslah berkonsep dan sesuai dengan kemampuan mahasiswa dalam memahami materi yang ada.

Keunggulan dari Aplikasi Kamus Tumbuhan Berspora yang dirancang, salah satunya adalah dibuat berdasarkan hasil studi tumbuhan berspora yang ada di TWA Pantai Panjang Kota Bengkulu, yang sering dijadikan lokasi untuk praktikum lapangan bagi mahasiswa Pendidikan Biologi UNIB. Dengan kata lain, aplikasi kamus tumbuhan berspora dibuat dengan memanfaatkan sumber belajar yang berbasis lingkungan sekitar sehingga lebih mudah untuk diaplikasikan dan dimengerti oleh mahasiswa karena objek tersebut berada dekat dengan mereka. Hal ini sesuai dengan penelitian Handini (2018) yang menyatakan bahwa bahan ajar (berlaku juga untuk media ajar) yang berorientasi pada karakteristik dan kearifan lokal dari suatu daerah akan lebih memberikan kesan yang nyata dalam pembelajaran sehingga akan lebih mudah untuk dipahami. Pernyataan yang serupa juga diutarakan oleh Prastowo (2011) yang mengungkapkan bahwa permasalahan yang diangkat dalam suatu pembelajaran harus berasal dari permasalahan yang nyata.

Penelitian dari Azhar (2016) dan Wulandari, dkk (2018) menunjukkan bahwa penggunaan media pembelajaran berbasis lingkungan/kearifan lokal merupakan alternatif media pembelajaran yang efektif dalam meningkatkan hasil belajar mahasiswa serta memberikan pengaruh positif dan juga signifikan terhadap minat maupun hasil belajar. 
Aplikasi kamus tumbuhan berspora juga dirancang dengan basis android, dengan kata lain, pembelajaran dengan menggunakan aplikasi berbasis android ini dapat dikategorikan pembelajaran mobile (mobile learning) sehingga pembelajaran bersifat fleksibel. Pembelajaran yang menggunakan perangkat smartphone dapat memberikan pembelajaran yang bisa dilakukan kapan saja dan dimana saja (Asabere, 2013). Hal ini juga diperkuat oleh pendapat Mehdipour dan Zarehkafi (2013) yang menyebutkan bahwa tipe pembelajaran mobile akan memberikan kesempatan belajar dimanapun dan kapanpun. Penelitian Park (2011) juga menyebutkan bahwa pembelajaran mobile akan sangat membantu siswa belajar secara mandiri.

Selain itu, keunggulan lainnya dari aplikasi kamus tumbuhan berspora yang dirancang adalah memuat gambar-gambar yang akan mempermudah mahasiswa dalam mengetahui dan memahami kata yang dituju, serta adanya submenu tinjauan pustaka yang akan mempermudah mahasiswa ataupun dosen dalam melacak buku, web, jurnal, atau artikel yang digunakan peneliti dalam perancangan aplikasi.

\section{PENUTUP}

\section{Simpulan}

Berdasarkan hasil uji validasi oleh dua validator dan uji respon mahasiswa, aplikasi kamus tumbuhan berspora yang dirancang dinyatakan layak untuk digunakan sebagai media pendukung perkuliahan TT I. Aplikasi kamus tumbuhan berspora dinilai sangat layak oleh dosen ahli materi dan dosen ahli media dengan rata-rata persentase skor sebesar 93,5\% dan direspon sangat baik oleh mahasiswa dengan rata-rata persentase skor sebesar $92,81 \%$.

\section{Saran}

Aplikasi kamus tumbuhan berspora ini sebaiknya diimplementasikan dalam proses perkuliahan di Pendidikan Biologi UNIB khususnya pada mata kuliah Taksonomi Tumbuhan I untuk materi tumbuhan berspora. Serta dilakukan pengembangan dan penyempurnaan untuk peneliti selanjutnya sehingga aplikasi dapat terus berkembang menjadi lebih layak dan bisa digunakan dalam jangka waktu yang panjang.

\section{DAFTAR PUSTAKA}

Angkowo, R. 2007. Optimalisasi Media Pembelajaran. Jakarta: PT. Grasindo.

Asabere, N. Y. 2013. Benefits and Challenges of Mobile Learning Implementation: Story of Developing Nation. International Journal of ComputerApplications, 73 (1).

Azhar. 2016. Pemanfaatan Media Berbasis Lingkungan dan Media Standar Laboratorium pada Pembelajaran Dasar-Dasar Sains di Program Studi Pendidikan Kimia FTK UIN Ar-Raniry. Banda Aceh: Fakultas Tarbiyyah dan Keguruan UIN Ar-Raniry Banda Aceh.

Budiman, M. A, Erna B.N, dan Riska V. B. 2015. Penerapan Algoritma Brute Force pada Perancangan Aplikasi Kamusta Bahasa Indonesia-Inggris Berbasis Android. Medan: USU Press. (Online). (http://repository.usu.ac.id/handle/ 123456789/46109), diakses 15 September 2018. 
Handini, M. N. 2018. Studi Etnobotani Tumbuhan Obat Suku Serawai sebagai Pengembangan Handout Biologi Kelas X SMA. DIKLABIO: Jurnal Pendidikan dan Pembelajaran Biologi 2 (2): 35-43. (Online).(http://ejournal.unib.ac.id /indexphp/ippb/article/view/6802) , diakses pada tanggal 20 Juli 2019.

Kamus Besar Bahasa Indonesia (KBBI). 2018. (Online). (https://kbbi.kemendikbud.go.id), diakses 30 Mei 2019.

Lawrence, G.H.M. 1951. Taxonomy of Vascular Plants. New York: John Wiley and Sons.

Lengkong, H.N, Alicia A.E.S, dan Arie S.M.L. 2015. Perancangan Penunjuk Rute Pada Kendaraan Pribadi Menggunakan Aplikasi Mobile GIS Berbasis

Android Yang Terintegrasi Pada Google Maps (E-journal Teknik Elektro dan Komputer). Manado: UNSRAT. (Online). (https://ejournal.unsrat.ac.id/index. php/elekdankom/article/download/ 6817/6341), diakses 15 September 2018.

Mehdipour, Y. dan Zarehkafi, H. 2013. Mobile Learning for Education: Benefits and Challenges. International Journal of Computational Engineering Research, 2 (6).

Park, Y. 2011. Pedagogical Framework for Mobile Learning: Categorizing Educational Applications of Mobile Technologies in Four Types.
International Review of Research in Open and Distance Learning. 12 (2).

Prastowo, A. 2011. Panduan Kreatif Membuat Bahan Ajar Inovatif. Yogyakarta: Diva Press.

Riduwan. 2013. Skala Pengukuran Variabel-Variabel Penelitian. Bandung: Alfabeta.

Sa'diyati, Feri. 2011. Pengembangan Bahan Ajar Materi Jamur Berbasis Kinerja Siswa. Semarang: UNS.

Sugiyono. 2008. Metode Penelitian Kuantitatif, Kualitatif, dan R\&D. Bandung: Alfabeta.

Tjitrosoepomo, G. 1991. Taksonomi Umum; Dasar-Dasar Taksonomi Tumbuhan. Yogyakarta: UGM Press.

Ulviani, Yemi. 2017. Pengembangan LKS Berdasarkan Identifikasi Tumbuhan Paku Epifit pada Batang Kelapa Sawit. DIKLABIO Jurnal Pendidikan dan Pembelajaran Biologi Vol.1 no. 1-2017.

(Online). (https://ejournal.unib.ac.id/index.ph $\mathrm{p} / \mathrm{jppb} / \mathrm{article/view/3171)}$, diakses 30 Mei 2019.

Widoyoko, E.P. 2016. Teknik Penyusunan Instrumen Penelitian. Yogyakarta: Pustaka Belajar.

Wulandari, S, Muliani A, dan Hamzah. 2018. Pengaruh Media Berbasis Lingkungan Terhadap hasil Belajar Murid Kelas V SD Inpres Kurunkung. Makassar: Universitas Muhammadiyyah Makassar. 